\title{
IMA-PANZO, João. Extensão universitária em Angola. Tendências, ações e projeções. Luanda: Mayamba, 2018. 171 p.
}

\author{
Ermelinda Liberato \\ Professora Auxiliar no Instituto Superior de Ciências da Comunicação (ISUCIC) \\ Luanda - Angola \\ Ermelinda.liberato@gmail.com
}

\section{Para citar- (ABNT NBR 6023:2018)}

LIBERATO, Ermelinda. Resenha. Eccos - Revista Cientifica, São Paulo, n. 55, p. 1-4, e16782, out./dez., 2020. Resenha da obra de Ima-Panzo, João. Extensão universitária em Angola. Tendências, ações e projeções. Luanda: Mayamba, 2018. 171 p. Disponível em:

https://doi.org/10.5585/eccos.n55.16782.

O presente livro de João Ima-Panzo, docente universitário e pesquisador, traz para o debate público a dimensão de uma das "funções substantivas que ocorre com o ensino e a investigação científica na definição do conceito de universidade moderna” (p. 61), o tema da extensão universitária em Angola - tendências, ações e projeções. Esse desafio, além de colmatar um vazio de informação relacionada com a temática para o contexto angolano, ainda apresenta possíveis caminhos que podem ser trilhados tendo em conta a alteração desse cenário, o que nos permite constatar, à partida, que se trata de um campo de ação universitário em construção.

Numa linguagem simples, que torna a obra acessível a um público heterogéneo, o autor propõe-se refletir em torno do conceito de extensão universitária, o surgimento, a sua posição na estrutura orgânica das Instituições de Ensino Superior (IES), a convivência com as outras áreas de ação das IES (ensino e pesquisa), o enquadramento à realidade angolana, a sua importância, bem como as inúmeras atividades que podem ser realizadas no seu âmbito de atuação, salientando a sua dimensão académica, científica e de formação humana. Para o efeito, o autor empreende uma análise dos principais documentos normativos que regulam o setor do ensino superior em Angola, com destaque para a Lei de Bases da Educação e Ensino (Lei 17/16, de 7 de outubro), as Normas Reguladoras do Subsistema de Ensino Superior (Decreto n ${ }^{\circ}$ 90/09, de 15 de dezembro), o Estatuto Orgânico da Universidade Agostinho Neto (Decreto 229/11, de 19 de agosto) bem como das restantes sete universidades existentes no país ${ }^{1}$.

${ }^{1}$ De salientar que o autor também se socorre da análise do estatuto da carreira docente, entretanto revogado pelo Decreto Presidencial n ${ }^{\circ} 191 / 18$ de 8 de agosto (novo estatuto da carreira docente do ensino superior). 
A obra está organizada em quatro capítulos, sendo que os dois primeiros são de enquadramento teórico e os dois últimos visam a sua operacionalização. $\mathrm{O}$ autor inicia o primeiro capítulo com uma resenha histórica, breve e sintetizada, sobre os caminhos da história da institucionalização da universidade (p. 23-35), onde somos informados que as universidades "são fruto da Idade Média na Europa" e que o "termo extensão resulta do alargamento das funções da universidade" (p. 27). Ainda neste primeiro capítulo, Ima-Panzo apresenta uma "breve contextualização histórica da universidade em Angola" (p. 29), desde a sua criação em 1962 como Estudos Gerais Universitários, dando ênfase ao período pós-independência até à atualidade, com a criação das regiões académicas.

As diversas tendências do conceito de extensão (p. 37-60) fazem com que o autor defenda a ideia que se trata de um conceito amplo e abrangente, daí defini-lo como "cultura, cidadania, conteúdos, ensino, investigação científica, práticas, experiências, valores, difusão, inter-relação, comunidade, empresa, sociedade e transformação" (p. 38). Neste segundo capítulo o autor começa por enquadrar a origem e desenvolvimento da extensão universitária em diferentes partes do mundo, justificando assim os diferentes modelos de extensão que se foram desenvolvendo. E como exemplo apresenta, na segunda parte do capítulo, a extensão universitária no Brasil, onde identifica o impacto e prevalência de três modelos, nomeadamente: a) modelo das universidades populares europeias, b) modelo das IES dos Estados Unidos da América e c) modelo expresso pelo manifesto de Córdoba. Ima-Panzo analisa ainda a "política nacional de extensão universitária brasileira" (p. 51) enumerando os seus objetivos, as "linhas orientadoras em que se promove a elaboração e implementação das ações de extensão" (p. 56), as ações políticas levadas a cabo e que visam o seu fortalecimento, bem como o financiamento.

Porém, o autor não justifica o porquê dessa opção pelo Brasil em detrimento de outros países lusófonos como Portugal, Moçambique ou Cabo Verde pois não encontramos qualquer relação com o caso angolano, objeto de estudo da obra. De igual modo, não identificamos nenhum acordo de cooperação nesse âmbito, e nem tão pouco sinais que aproximam os dois países nesse quesito. Uma reflexão mais atenta e profunda sobre o assunto levanta outras indagações como o fato de não percebermos o porquê da inspiração em cópias de modelos importados de outras latitudes, sem qualquer enquadramento à realidade angolana, em detrimento da criação de modelos próprios e das suas vivências. Fica aqui uma pista para futuras reflexões.

Nas páginas seguintes (61-112) o autor apresenta os resultados da sua pesquisa sobre a extensão universitária em Angola (Capítulo III). Ima Panzo inicia o capítulo com a com a delimitação do seu estudo "abordar os principais acontecimentos normativos em que se 
fundamenta a extensão universitária nas IES públicas” (p. 61), não abarcando outras IES públicas (escolas superiores e institutos politécnicos) bem como público-privadas e privadas, empreendendo assim uma análise ao "conjunto de normas, leis, decretos-lei, decretosexecutivos e outras específicas" (p. 62) que sustentam a atividade universitária em Angola.

Pela análise dos referidos documentos normativos o autor constata que a utilização da expressão extensão universitária "assume um caráter marcadamente confuso, sem identidade terminológica na definição do conceito de universidade" (p. 69). Ima-Panzo destaca ainda a marginalidade institucional da extensão, o que faz com que a afetação de recursos humanos, físicos e infraestruturais não sejam definidas, a não progressão na carreira para os docentes envolvidos justifica a ausência de carga horária e vinculação curricular, o que faz com que esta se encontre numa situação "pouco favorável” (p. 71). No entanto, essas condicionantes, apesar de constituírem um entrave para o desenvolvimento das atividades, não desencorajam algumas IES mais destemidas, como foi o caso da Escola Superior Politécnica do Bengo (ESPB) e do Centro de Investigação Científica e Assessoria Jurídica (CICAJ) da Universidade Lueji A’Nkonde, na Lunda Norte.

Por conta dessa situação, o autor apresenta, no quarto capítulo, alguns subsídios para a sua institucionalização (p. 113-163), tendo como base a sua experiência de trabalho em atividades de extensão e a revisão da literatura especializada sobre a temática. $\mathrm{O}$ autor propõe assim a criação de um quadro de Referências para a Extensão Universitária (QRExU) cuja estrutura comporta uma Política de Extensão Universitária, que corresponde a um "quadro jurídico-legal que suporte e legitime toda e qualquer ação de extensão universitária a ser desenvolvida no interior das IES” (p. 114), uma Política de Extensão Universitária das IES, que corresponde à "adoção da extensão universitária como função estruturante da vida académica" (p. 121), bem como o estabelecimento de níveis Comuns de Referência por tipologia, que visam salvaguardar a qualidade das ações de extensão.

Este último capítulo é particularmente interessante na medida em que há uma proposta que visa a institucionalização da extensão, bem como os critérios que garantam o seu desenvolvimento uniforme a nível nacional. O que constitui um reconhecimento sobre a sua relevância enquanto área do conhecimento e a sua ligação às outras funções da universidade (ensino e pesquisa). Porém, a qualidade do ensino ministrado e a quase ausência da pesquisa nas IES angolanas, leva-nos a questionar a sua implementação num futuro próximo. Aliás, os próprios documentos normativos, recentes na sua maioria, são muito incipientes nesse sentido, condicionando, à partida, o seu desenvolvimento. Por outro lado, e como bem analisou o autor, o fraco enquadramento normativo, o não reconhecimento das atividades como parte integrante 
do processo de ensino-aprendizagem, a ausência de vinculação da atividade docente, entre outras lacunas, colocam as atividades de extensão universitária numa posição marginal, como se de atividades de tempo livre se tratassem. Urge, pois, o seu reconhecimento a todos os níveis bem como a sua dignificação.

A análise crítica em torno desses documentos é de aplaudir. No entanto, sentimos falta de uma análise mais complexa em relação ao conceito e importância da extensão universitária, tendo como suporte outros documentos científicos já produzidos em outras latitudes, seja a nível regional, continental ou internacional. Assim, uma pista para futura pesquisa e reflexão teórica será a expansão do foco de análise para as dinâmicas de extensão a nível das IES, focando nas conexões entre os cursos e a oferta académica de cada IES com a sociedade e as necessidades do mercado de trabalho. Numa época em que a crise, nas suas múltiplas dimensões, conquistou o terreno e parece ter-se enraizado e consolidado como palavra de ordem, servindo de desculpas para toda e qualquer (in)atividade das instituições no geral, o livro de Imã-Panzo constitui um contributo indispensável para acreditarmos que esta pode abrir caminhos desconhecidos. 